\title{
DESIGN OF TEMPERATURE AND AIR HUMIDITY MONITORING INFORMATION SYSTEM BASED ON ANDROID AND IOT (INTERNET OF THINGS)
}

\author{
Alexander Victor Bukit ${ }^{1}$, I Nengah Putra A $^{2}$, Febryan Galih Rahardi ${ }^{3}$, Ahmadi ${ }^{4}$ \\ 1,3,4 Indonesia Naval Technology College, STTAL Surabaya Indonesia \\ 2Indonesia Defense University, UNHAN Jakarta Indonesia
}

\begin{abstract}
ABSTRAK
For a soldier, physical abilities are needed in every task implementation, so the daytime running activities become a compulsory menu for every soldier who is carrying out education. Both the basic military education and further education. According to health experts, benefit of jogging is to lose weight so as to avoid obesity, improve the ability of the lungs, heart and various other health benefits. However, we also have to pay attention to the temperature of the air because it is at a certain temperature, it will be very risky if we carry out the afternoon run. Not a few victims affected by heat stroke due to run during the day with high air temperatures. The current mechanism, temperature measurements are carried out manually by members of the local Satkes, then the Satkes report the results of temperature measurements to Binjas and then Binjas decide whether or not to run afternoons that day. After the decision was made, the Binjas reported to the guard division and the guard to spread the news through the prayer watch. Therefore, with this android-based temperature and humidity monitoring information system, we can easily find out whether today's temperature is safe or not to carry out daytime running activities.
\end{abstract}

Keywords : Afternoon Run, Heat stroke, Android.

\section{INTRODUCTION}

\subsection{Background}

The Navy as one of the dimensions of the $\mathrm{TNI}$ has several Educational Institutions (Lemdik) which aim to change ndividual behavior into a formidable and reliable soldier. Educational institutions are filled by Permanent Members (antap) and also students from various strata who are currently undergoing development or further education. In addition to academic lessons, students and personnel in educational institutions are also required to carry out physical training so that the condition of the body and health is always maintained.

One of the physical activities that is routinely carried out in educational institutions is the morning run and the afternoon run. Specifically for the afternoon run, the trainers or student guides (bingsis) are expected to know the temperature and humidity of the weather on that day. So that undesirable things don't happen, one of them is Heat Stroke. Heat stroke occurs due to physical activity carried out at external temperatures and high humidity.

Current mechanism, before running in the afternoon, the Health Unit (Satkes) related educational institutions will measure the Wet Bulb Globe Temperature (WBGT), which is a measurement of heat-stress from direct sunlight, and takes into account: temperature, humidity, wind speed solar radiation. This is not the same as the heat index, which only takes into account temperature and humidity for shaded areas.

After the Satkes has finished carrying out the WBGT calculation, the Satkes then reports it to the Physical Development Board (Binjas). After that, Binjas decided that no afternoon running would be done. Then the decision is reported to the guards and the guards announce the temperature / WBGT index through the speaker / prayen so that all members know.

From that, it is necessary to design and construct a WBGT temperature and humidity measurement system within the Institute of Education using more effective and efficient methods. One method that can be developed to meet these needs is the method of monitoring temperature and humidity using the DHT11 temperature and humidity sensor with Wemos D1 wifi placed in the open air which is considered to represent educational institutions and can be accessed via a smartphone that has the application installed android. So that the local air temperature and humidity in the educational institution will be known in real-time 
through the Android smartphone of each personnel.

With the design, it is hoped that it can help the soldiers to find out the latest temperature conditions in educational institutions on any day and at any time. Due to temperature measurements carried out at Kodiklatal currently only carried out on Wednesday before the daytime running activities.

\subsection{Problem Formulation}

Based on the description of the background of the above problems, it can be formulated a problem that is how to design and build monitoring of temperature and humidity information that can be reached and accessed by all personnel of educational institutions quickly and in real time

\subsection{Research Objectives}

The purpose of this research is to make a design of an information system for monitoring temperature and humidity to make it more practical and efficient for both Satkes, Binjas officers, and for educational institution personnel.

\subsection{Research Benefits}

The benefits of holding this research are:

a. For Members and Students of Educational Institutions:

1) Obtain real-time temperature information at any time through the respective smartphone

2) No need to wait for information from the security to find out the temperature and humidity of the air.

3) Temperature information can be accessed from anywhere and any day as long as there is an internet signal.

b. For Satkes and Jasrek Personnel Educational Institutions:

1) No need to take temperature measurements manually like the previous procedure.

\section{LITERATURE REVIEW}

\subsection{Information Systems}

Information system, according to (Rommey, 1997) is a system that is organized by collecting, entering, processing, and storing data which is then organized to store, manage, control, report information in a certain way to achieve the goals set.
The implementation of special information systems for national defense becomes something that needs to be developed in the implementation of accountable national defense. This information system is a single entity that cannot stand alone and must be integrated with others so that it will be easy to update all changes and developments that occur both from internal and external of the defense information system. The TNI information system as part of the national defense information system was developed and developed by the TNI Headquarters under the Supervision of the Ministry of Defense to lead to a design based system, which is to build and enrich an information technology based system. This system also provides data and information services in order to support the implementation of national defense which includes internal services to achieve the goals of bureaucratic reform within the Ministry of Defense and the TNI (Dr.Ir Supartono MM, 2014).

\subsection{WBGT (Wet Bulb Globe Temperature)}

WBGT is a measurement of heat stress from direct sunlight, taking into account: temperature, humidity, wind speed, and solar radiation. Unlike the heat index, which only takes into account the high temperature and humidity calculated shady areas (Juanda, 2003). Military institutions from various countries use the WBGT as a reference in managing workloads in direct sunlight. WBGT is often used by military, athletes, and industrial hyginists to determine the level of exposure at high temperatures.

WBGT is calculated by a formula that involves air temperature, air movement, heat radiation from sunlight and cooling the body by evaporation of sweat. Air temperature is measured using an ordinary thermometer. Radiant heat is measured using a black globe thermometer. Conventional thermometers are inserted into a hollow rubber stopper, into a copper ball coated in black paint. The black globe thermometer is positioned in the center of the copper ball and takes 20 minutes to read.

\begin{tabular}{|c|c|c|c|}
\hline GENDERA & SUKU & RESINO & REKOMENDASI \\
\hline \multirow{2}{*}{ PUTIK } & $<27,7 \mathrm{CC}$ & \multirow{2}{*}{ TIDAKADA } & \multirow{2}{*}{ Altivites normal } \\
\hline & $\angle 82^{\circ} \mathrm{C}$ & & \\
\hline HUAU & $\begin{array}{c}27,7^{\circ} \mathrm{C}-30,5^{\circ} \mathrm{C} \\
8 \mathrm{EF}-86,9^{\circ} \mathrm{F}\end{array}$ & RENDAH & Aktwites normal \\
\hline \multirow{2}{*}{ KUNING } & $30,6^{\circ} \mathrm{C}-32,1^{\circ} \mathrm{C}$ & \multirow{2}{*}{ SEANG } & \multirow{2}{*}{ Resiko meninglet ketika kegibtan berlangsung sepandang harl } \\
\hline & $87 \mathrm{~F} .89,9 \mathrm{gF}$ & & \\
\hline MERAH & $\frac{32,2^{\circ} \mathrm{C}-33,3{ }^{3} \mathrm{C}}{90^{\circ} \mathrm{F} \mathrm{K}^{2} \mathrm{~F}}$ & TNGGI & Set tiap persone I hans me waspadal potensi cedera \\
\hline \multirow{2}{*}{ нтАM } & $233,3^{\circ} \mathrm{C}$ & \multirow{2}{*}{ ESTRM } & \multirow{2}{*}{ Pertimbangran penjadwalan ulang atay menunda sampal suhu ama } \\
\hline & 2927 & & \\
\hline
\end{tabular}

Figure 1 Categories of Physical Activity based on WBGT Temperature 


\subsection{Android}

2.4 Android is a Linux system based on mobile devices such as smartphones and tablets. Android was originally developed by Android, Inc. This operating system was officially launched in 2007 with the opening of the Open Handset Alliance, a consortium of hardware, software and telecommunications that promotes open standards for mobile devices. The first Android phone was launched in October 2008.

Android is an open source operating system, launched by Google under the Apache license. With open source and Android licenses, software can be modified independently and distributed to manufacturers, wireless operators, and application developers. In addition, Android has many community developers who go beyond the capabilities of the device, which are usually written using a special version of the Java programming language.

In October 2013, more than one million Android applications were available and around 50 billion were downloaded by users from Google Play. A survey conducted in April-May 2013 found that Android is the most popular platform with $71 \%$ of mobile application developers using it. At Google I / O 2014, Google reported that there were more than one billion monthly Android users out of $\mathbf{5 9 3}$ million in June 2013.

\section{RESEARCH METHOD}

\subsection{Research Design}

This type of research in this thesis uses applied research methods (practical research) as research that can be utilized to solve problems. Research is carried out using, testing and evaluating practical issues to be beneficial to human interests, individual interests and group interests. Determination of applied research problems to find solutions to problems that can be utilized by humans. Therefore the results of this study do not have to be new discoveries, but rather are new applications of existing research. This research does not have to focus on developing an idea, a theory or an idea, but rather prioritizing an application of research in daily life.

\subsection{Research Procedure}

The research procedure is an explanation of the research process to be carried out, starting from the system design work diagram to the expected system input and output. The overall research process can be seen in Figure 2 Following is the Flowchart of the research procedure.

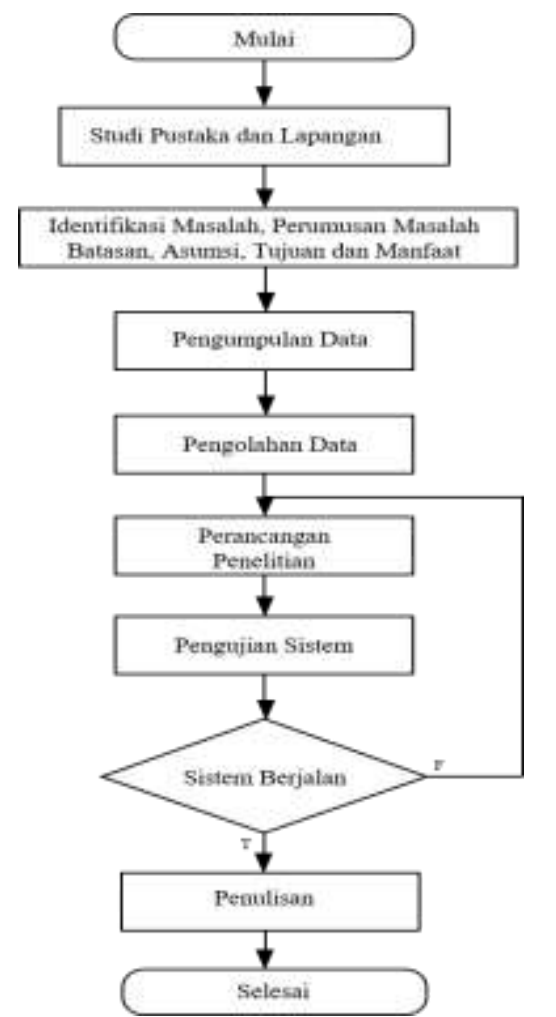

Figure 2 Flowcart Research procedure

\subsection{Time and Place}

The time for the final research that has been carried out is from August to November 2019 while the place for conducting research in the Surabaya Health Office is as a place to retrieve data, while the program and tool trials are carried out at Kodiklatal and STTAL.

\subsection{Tools and Materials}

In carrying out this research, several tools and materials are needed to facilitate the design and trial of research. The tools and materials needed in conducting the research include:
a. The laptop.
b. Android smartphone.
c. Wemos D1
d. Arduino IDE
e. DHT11 temperature sensor.
f. MySQL Database Software.
g. PHP programming language.
h. Android Studio Application.

\subsection{Research Design}

The system design will be carried out after an analysis of the system, which in the 
design of this system can provide an overview of the system to be made. The general description of the system to be made is as follows:

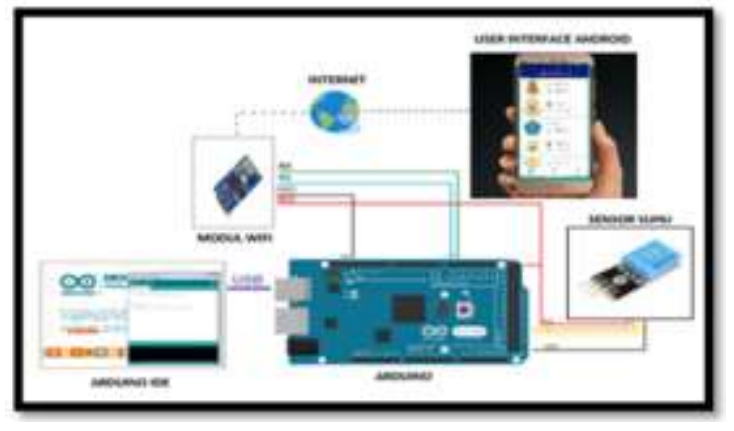

Figure 3 Overview

\subsection{System Design}

According to (John Burch and Garry Grudnitski, 1986), "system design can be determined as drawing and sketching or arranging separate elements into one, all working together." From this definition it can be concluded that the system design is the stage of drawing, planning and making to unite several separate elements in a unified system to clarify the system.

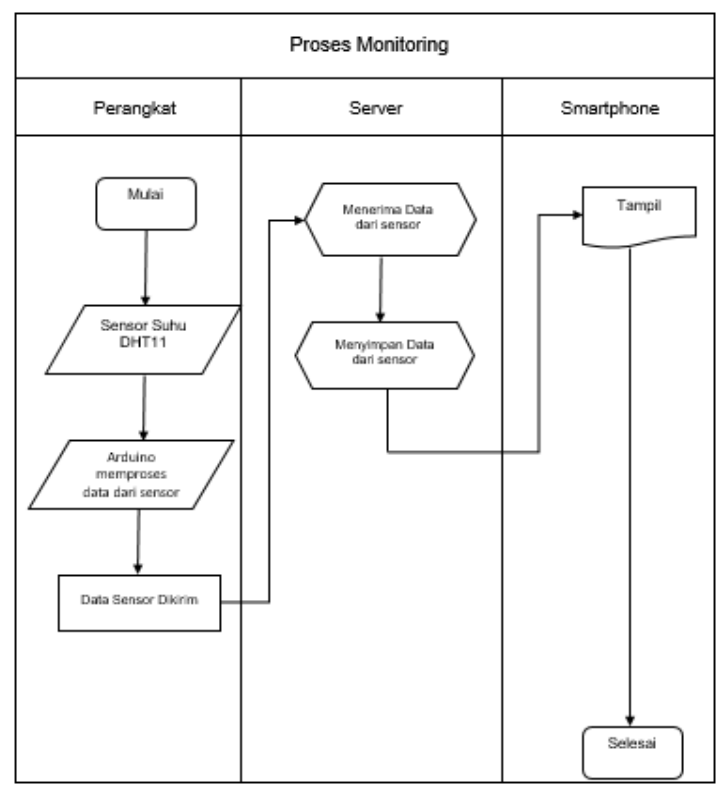

Figure 4 Flowchart Monitoring Process

The process of monitoring temperature and humidity is illustrated in Figure 3.4. The need for a sensor as an input to detect and monitor how much the temperature and humidity of the air. Detection results from the sensor are processed by Wemos D1 and uploaded to the esp8266 wifi module, the reading data is stored in a database server to later be displayed on an android application that is accessed by users from the smartphone.

\subsection{Data Collection}

The methods used to collect data in this research system are:

a. Observation method is a method of collecting data by means of making observations directly on the data relating to research, in this design the writer will observe the temperature measurement activities manually carried out by members of the Health Unit in the period August 2019 and make comparisons in the use of tools that are used as well as how to read them based on temperature categories, so the authors get the information needed to complete the data making design of the tool.

b. Interview method is a method of collecting data by way of question and answer which is directly to the interviewees relating to the data needed in this study. The interview method was conducted directly with the Kodiklatal Satkes personnel who were tasked with manually measuring the WBGT temperature. Include Apm Arief Sayuti.

c. Literature study method is a method of data collection which is done by finding references from books, journals and internet media related to this research, in this design the author plans to visit the STTAL library and look for several books in Gramedia Stores and use the internet media to search for journals. -journals related to the design of the tool.

\subsection{Data Processing}

Data processing is the data processing stage, where the data that has been collected is processed to become a useful information for the user. The steps that need to be considered in data processing are data preparation and data classification.

In compiling data, all existing data must be collected so that it is easy to check whether all necessary data has been obtained. This activity aims to obtain data results that have something to do with data from research results and are truly authentic. The data must be separated according to data collection techniques, time, and where the data was taken. Classification of data is an attempt to group, classify and select data based on the classification that has been made and that has been determined by researchers.

This data processing aims to test research on a predetermined problem formulation. The next process is analyzing data 
and making conclusions about the series of activities that have been carried out, in which explain the framework and systematic research and difficulties in research. In this study, data processing is based on data from the Surabaya Kodiklatal Satkes.

\section{ANALYSIS AND DISCUSSION}

\subsection{Design}

Design is a process carried out on a project that will be done, starting from the research design, to the finished results that will be functioned. In principle, good design and systematic design can make it easy in the production process to become an application system that truly functions as it should. In the design of temperature and humidity monitoring systems in the Navy's educational institutions consists of several designs, namely the design of hardware and software used to build applications.

\subsubsection{Hardware Design}

Hardware or also referred to as hardware is a device that can be touched and can be seen in plain or tangible form. This hardware trimmer functions to support the work of the system to be created. In designing hardware, namely by determining the form of design of tools that are made so that it can support the success of the workings of the system. And what electronic devices are used in the circuit that produces a system.

Design of Temperature Sensor and Humidity Sensor Circuits. In this section there are several main tools that are part of the design of the system that will be built, including the DHT11 temperature sensor as an input device for temperature and humidity data and a WiFi module as a data transfer tool to the server, the two devices are assembled with the Wemos D1 wifi microcontroller and the battery so into a series of interconnected systems that will produce an electronic circuit in this temperature and humidity monitoring system.

\subsubsection{Software Design}

Software or software can be called a special term for data that is formatted and stored digitally, including computer programs, documentation, and various information that can be read or written by a computer. In designing software for Arduino Nano is to use the $C$ programming language which is open source software. The advantage of open source software is that the command to run a sensor or module can be done by anyone and according to the wishes of the program maker. Then the program that has been created is uploaded to the microcontroller. Program commands will be stored in EEPROM or called Electrically Erasable Read Only Memory which is storage memory that stores configuration data that is maintained or not erased when the power source is disconnected and then revived.

\section{a. Login Form Design}

Login form design is a form intended for Admin who has access to enter the system. Not everyone can log in, because only certain parties have access in the form of a username and password. Login form design can be seen in Figure 5.

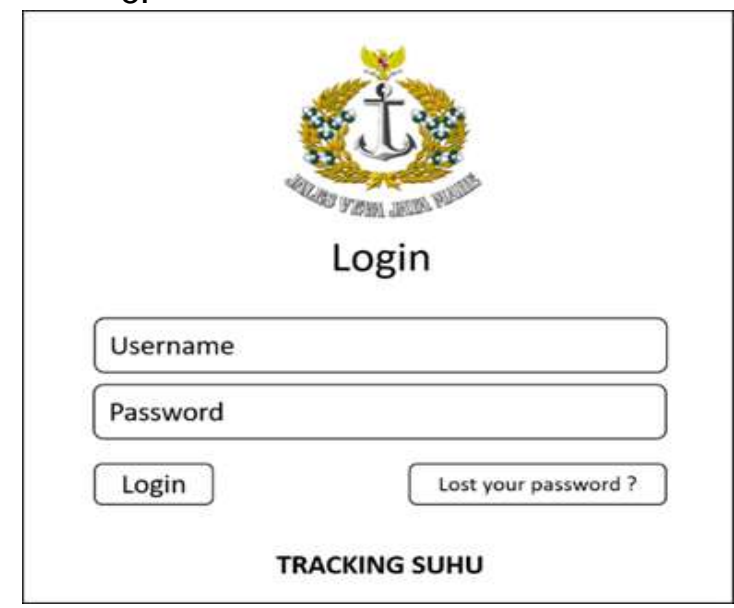

Figure 5 Log In page design

b. Home Page Design

The Home / Dashboard Design is a design to display a visual interface that presents information needed for a specific purpose and is the initial display encountered when a user enters the system and can only be seen by the Admin by logging in first. Dashboard design can be seen in Figure 6.

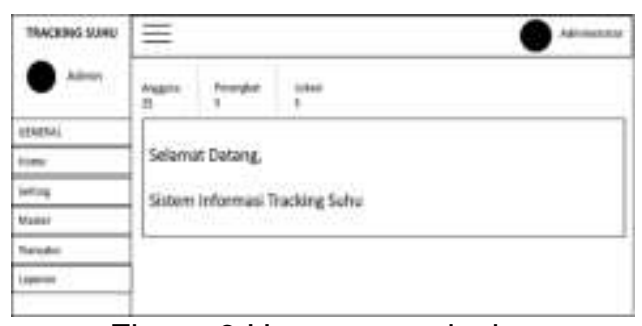

Figure 6 Home page design

c. Master Data Design

In the Master data there are rank data, member data, location data and device data. Master Data is the main data or core data in the server 
website. The master data design can be seen in Figure 7.

\begin{tabular}{|c|c|c|c|c|c|}
\hline \multirow{3}{*}{$\begin{array}{l}\text { TRACENG SUHU } \\
\text { Aderin }\end{array}$} & \multicolumn{3}{|l|}{$\equiv$} & \multicolumn{2}{|c|}{ Adninisntor } \\
\hline & \multicolumn{5}{|c|}{ Moser I Prods } \\
\hline & Avogut & Menew & & & \\
\hline \multicolumn{6}{|l|}{ GEVERLL } \\
\hline Hone & & Pancie & \multicolumn{3}{|c|}{ Ahi } \\
\hline Exting & & Adninitutor & tot & Dentets & \\
\hline Mater & & robonet & Eat & beleter & \\
\hline Arewest & & Letelol & tet & Delete & \\
\hline iabi & & Mepr: & list & Wett & \\
\hline Drieds & & Sopten & ftat & Dekite & \\
\hline 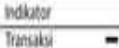 & & uev & $16 \mathrm{t}$ & Devet & \\
\hline
\end{tabular}

Figure 7 Master Data Design

\subsection{Implementation}

Implementation as an application or the result of a design derived from an idea is then carried out a study. Implementation or application of the results of the design above is the implementation of hardware and software implementation where this implementation produces a system that can be used properly by users who want to know the temperature and humidity in real time.

\subsubsection{Hardware Implementation}

Hardware is the physical components of the equipment needed and assembled to form a computer system. The hardware used in the design system for monitoring temperature and humidity in the Navy's educational institutions is:

a. Series of Temperature Sensor Devices

In hardware implementation, it uses Wemos D1 which has a wifi sensor attached to it. Then connected to the temperature and humidity sensors DHT11. Wemos boards are made with acrylic protectors to make tools safer. For temperature sensors DHT-11 remains outside the acrylic so that its function is more optimal. In terms of power, 2 options are provided, namely using batteries and adapters so that their utilization can be more flexible. The way this tool works, the tool sends data to a server with a wifi network via the HTTP / GET protocol. Data consists of date data, time data, temperature data, humidity data, location data, temperature category flag data and risk data. All commands are stored in memory Dem wemos and then sent to the server.

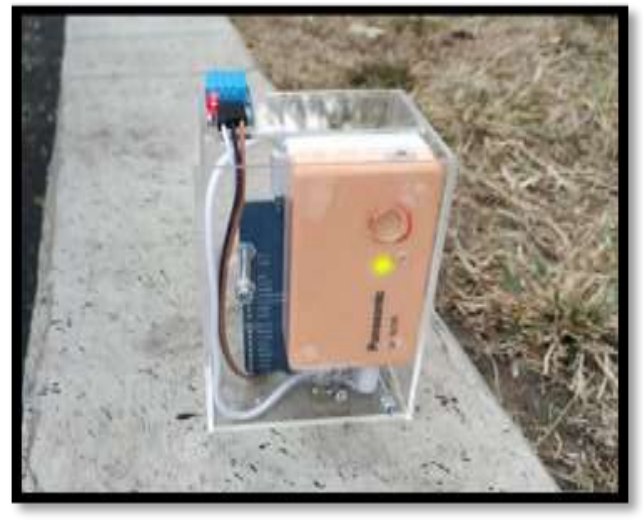

Figure 8 Front View

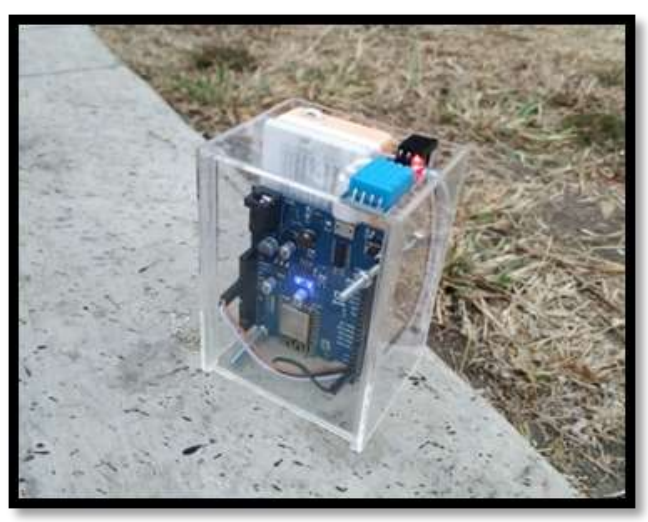

Figure 9 Rear View

\subsubsection{Software Implementation}

Software is an inseparable part of the hardware. Understanding software can be interpreted as a collection of electronic data that is stored and regulated by a computer in the form of programs or instructions to execute and execute a command. In the implementation of the design software system monitoring temperature and humidity that is used can be seen in the following table:

Table 1 Software used

\begin{tabular}{|c|l|l|c|}
\hline No & \multicolumn{1}{|c|}{ Nama } & \multicolumn{1}{|c|}{ Perangkat Lunak } & Ket \\
\hline 1 & Sistem Operasi & - Windows 7 & \\
\hline 2 & Basis Data & - MySql & \\
\hline 3 & Perangkat lunak & - Android Studio 3.0.1 & - Java \\
& Pemrograman & - Arduino IDE & - C++ \\
\hline 4 & Protokol & - HTTP / GET & \\
\hline
\end{tabular}

a. Log In page

Login can only be done by the Admin to be able to access the web server. When this website is opened, the first display that appears is the Login view which will ask the application access to enter a user name and password as a condition for being able to access the website. Login page display can be seen as in Figure 10. 


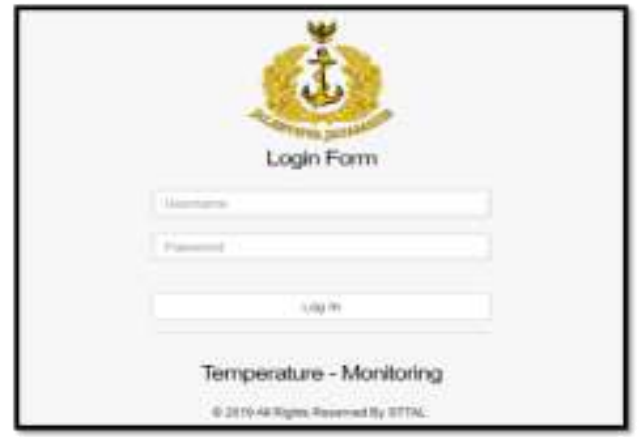

Figure 10 Log In Page

b. Home page

The home page on the temperature and humidity monitoring application contains several menus on the web server. The initial display goes directly to the dashboard on the Home menu.

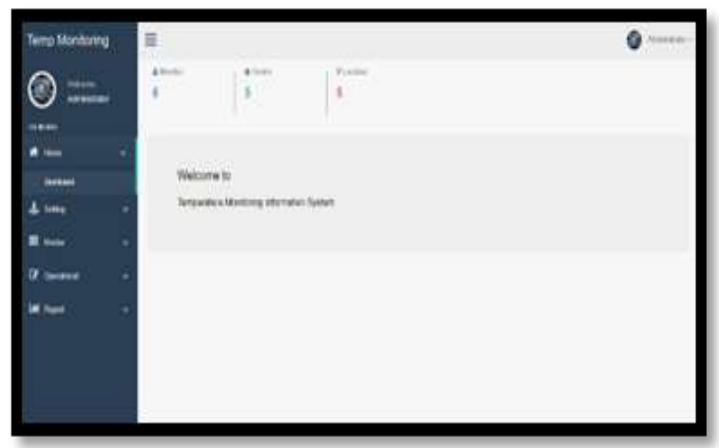

Figure 11 Home page

c. Halaman Setting

Pada menu setting, terdapat sub menu Change Password, yaitu suatu layanan untuk memfasilitasi admin mengganti password dalam mengakses website.

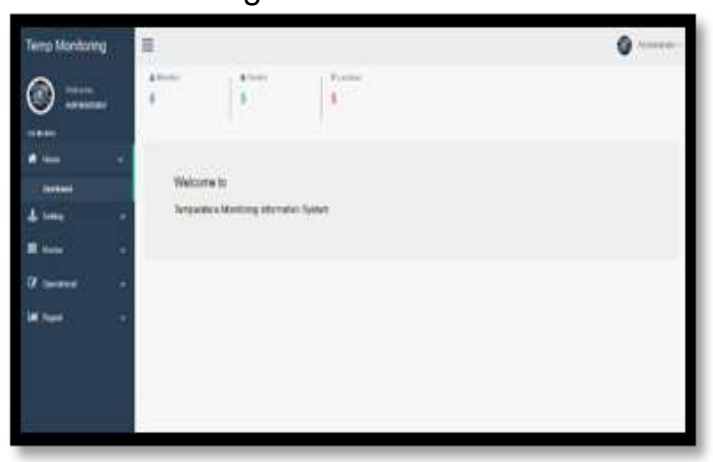

Figure 12 Settings page

\section{d. Master Data Page}

The Master Data page contains the main data on the website, including: rank data, member data, location data, device data and indicator data.

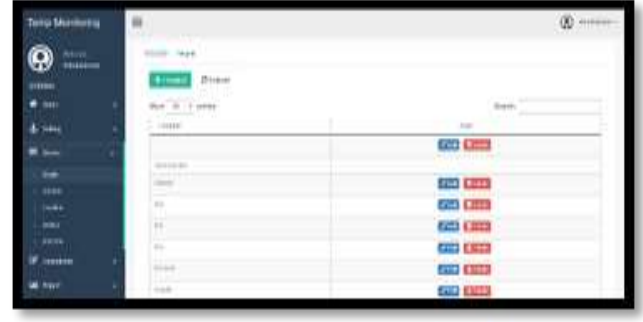

Figure 13 Rank Data

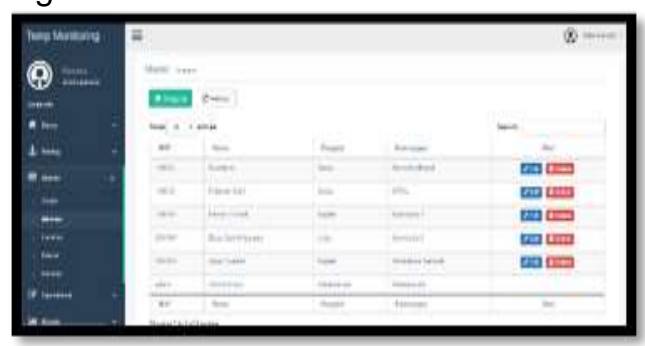

Figure 14 Member Data

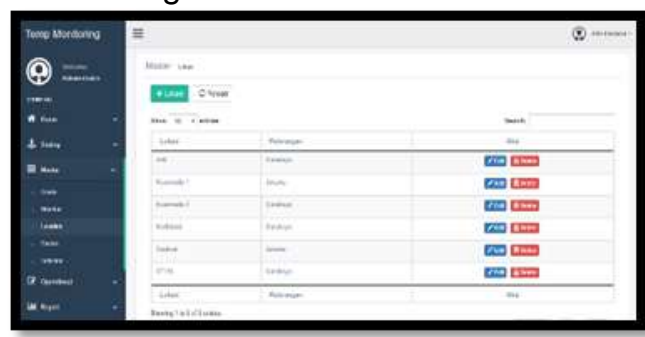

Figure 15 Location Data

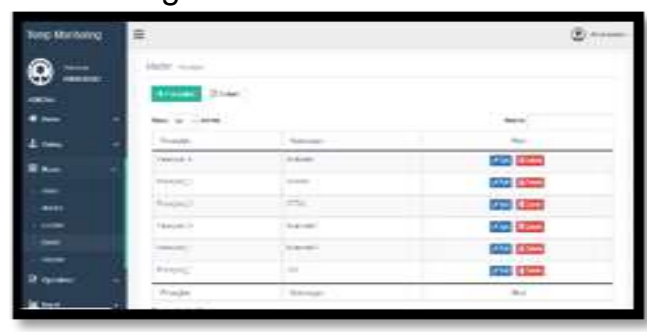

Figure 16 Device Data

\subsection{Testing}

The purpose of testing Internet of Things (IoT) for monitoring systems of temperature and humidity in the Navy's educational institutions is to determine the ability of several processes carried out in the system being built. The testing of this system is carried out on software and hardware to find out and prove the results of the designs made.

\subsubsection{Hardware Testing}

Hardware testing is carried out to determine the working capability of the equipment installed in this temperature and humidity monitoring system. Tests carried out on the temperature sensor is able to capture the high and low temperatures well in the open air because it will determine the accuracy of the data received. 
Testing is also carried out on the ability of WeMos D1 in capturing hotspot signals and sending data to be received by the server and can be accessed through the android application. The sensor is given a $5 \mathrm{~V}$ dc input voltage and the analog output is connected to the Arduino WeMos which has been connected to the computer.

The first test is the WeMos D1 WIFI test. Testing is done by connecting WeMos D1 to a $3.3 \mathrm{~V}$ voltage source. Upload an empty sketch to Arduino, next to the SSID settings and WIFI Hotspot password on the serial monitor. If the module is detected at the hotspot and the serial monitor module has obtained an IP, the module is working properly. The WIFI module display that is connected to the hotspot can be seen in Figure 17.

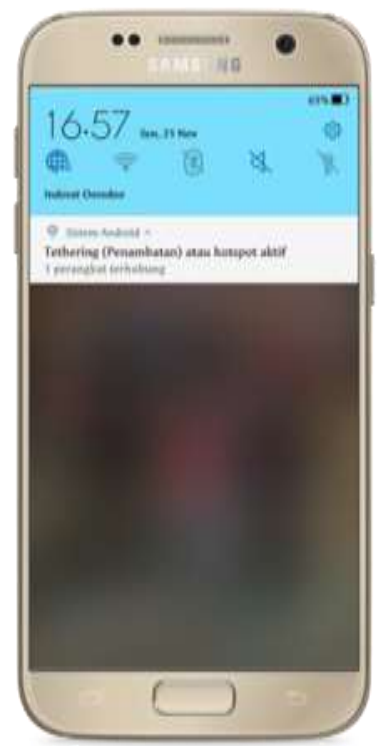

Figure 17 Wifi Connected Device

\subsubsection{Software Testing}

Software testing is carried out to determine the extent of the ability of the Internet of Things (IoT) software for information systems for monitoring temperature and humidity in the Navy's educational institutions. Software testing conducted on this system is reading the temperature and humidity of the air so that it can find out how high the temperature and humidity are measured, the process of connecting devices to the internet, the process of sending data from the device to the server, the process of logging in, the process of inputting data, the process of reading data from the database, Report printing process, and logout process. Testing this system can be seen in table 2.
Table 2 Software Testing Table

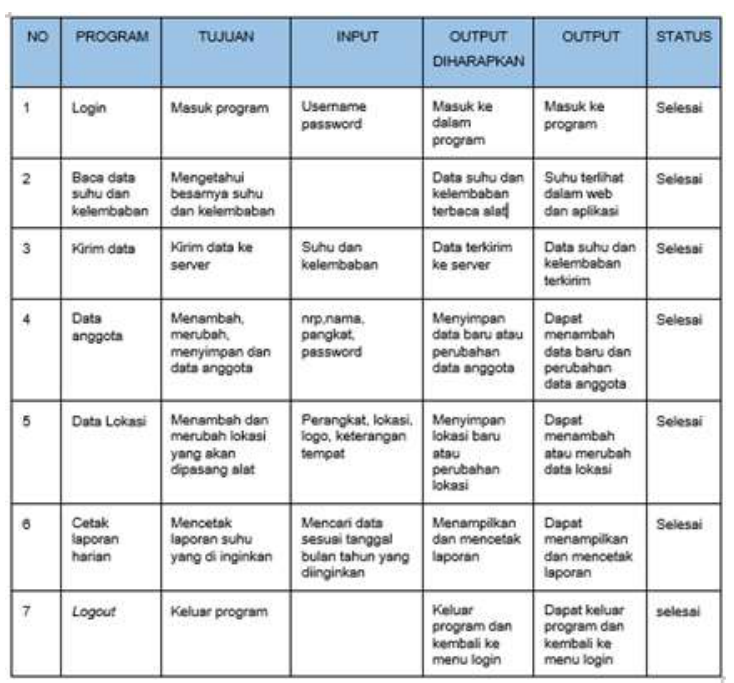

\subsection{Results and Discussion}

\subsubsection{Results}

Research on the design of information systems for monitoring temperature and humidity in the Indonesian-based TNI AL and IoT (Internet of Things) educational institutions was carried out by testing the whole system. The results were obtained based on testing conducted on temperature measurements through the DHT11 sensor by reading the temperature and humidity in the Dewaruci Kodiklatal field. The test results concluded that the sensor can capture temperature and humidity data and send it to the server as long as the sensor and WeMos D1 are connected to a wifi signal. The following is a table of test results for temperature measurements with DHT11 sensors and thermometers.

\section{Table 3 Sensor test results}

\begin{tabular}{|c|c|c|c|c|}
\hline No & Waktu Uji & Weather.com & Thermometer & DHII1 \\
\hline 1. & $01: 30$ WIB & $28^{\circ} \mathrm{C}$ & $28^{\circ} \mathrm{C}$ & $29.6^{\circ} \mathrm{C}$ \\
\hline 2. & $04: 00$ WIB & $28^{\circ} \mathrm{C}$ & $27^{\circ} \mathrm{C}$ & $27.5^{\circ} \mathrm{C}$ \\
\hline 3. & 08.00 WIB & $33^{\circ} \mathrm{C}$ & $31^{\circ} \mathrm{C}$ & $32.9^{\circ} \mathrm{C}$ \\
\hline 4. & $10: 00$ WIB & $33^{\circ} \mathrm{C}$ & $33^{\circ} \mathrm{C}$ & $34.1^{\circ} \mathrm{C}$ \\
\hline 5. & $10: 30$ WIB & $34^{\circ} \mathrm{C}$ & $34^{\circ} \mathrm{C}$ & $35.7^{\circ} \mathrm{C}$ \\
\hline 6. & $13: 45$ WIB & $35^{\circ} \mathrm{C}$ & $36^{\circ} \mathrm{C}$ & $36^{\circ} \mathrm{C}$ \\
\hline 7 & 14.30 WIB & $35^{\circ} \mathrm{C}$ & $35^{\circ} \mathrm{C}$ & $35.8^{\circ} \mathrm{C}$ \\
\hline 8. & $16: 00$ WIB & $35^{\circ} \mathrm{C}$ & $34^{\circ} \mathrm{C}$ & $35.7^{\circ} \mathrm{C}$ \\
\hline
\end{tabular}

In Table 3 it can be concluded that testing between thermometers, weather.com, and DHT11 temperature sensors has the largest error margin of $1.9^{\circ} \mathrm{C}$. This is in accordance with the specifications of the DHT11 sensor which has an error margin of $\pm 2{ }^{\circ} \mathrm{C}$. 


\subsubsection{Discussion}

Research on the Design of Information Systems for Monitoring Temperature and Humidity in the Navy and Android-based Naval Education Institute is an type of applied research, because this research has the aim to provide solutions and focus more on the application of duty in daily life. . This research can help students and coaches in educational institutions to find out the accurate and realtime temperature and humidity conditions before carrying out jogging. This study also uses engineering methods because this research applies science into an effective and efficient system design.

This research was conducted based on the needs of the organization, especially access to temperature information at the Navy's educational institutions, so that students and students could calm down and not worry before carrying out the daytime running activities. With this system, the parties can easily find out the amount of temperature and humidity at that time. So as to minimize the presence of heat stroke stroke caused by daytime running activities carried out at temperatures that are not recommended.

\section{Conclusions and Recomendation}

\subsection{Conclusions}

After carrying out the design process and making the application and testing has been carried out on the Temperature and Humidity Monitoring Information System at the NavyBased Education Institute for Android and IoT (Internet of Things), the following conclusions can be drawn:

a. This tool can display temperature and humidity information in realtime, display the temperature category flag in accordance with the WBGT (Wet Bulb Globe Temperature) procedure, display and print temperature history according to the desired date.

b. This tool can be used in open and closed areas as long as the device is connected to wifi, so the temperature data captured by the temperature sensor can be sent to the web server.

c. The process of sending temperature data from the sensor to the web server is very dependent on the quality of the wifi signal, as well as the process of access from the android application to the web server also depends on the quality of the smartphone signal.

\subsection{Recomendation}

Based on observations of the Design of Information Systems for Monitoring Temperature and Humidity of the Navy-based Android and loT (Internet of Things) Educational Institute, then the following Recomendation can be given:

a. To increase data accuracy, the DHT11 sensor can be replaced with a BMW PrexaParts Sensor so that the temperature data captured is more accurate.

b. In its development, the use of the wifi module in the device can be replaced with the GSM SIM800L module, so that the device can be independent and not dependent on the wifi signal in the surrounding buildings.

c. The design is expected to be developed further which in the end can support activities in the field for TNI educational institutions so that students / members who want to run in the afternoon are not alarmed and can avoid the danger of heat stroke.

\section{ACKNOWLEDGEMENT}

The authors greatly acknowledge the support from STTAL Surabaya and UNHAN Jakarta Indonesia for providing the necessary resources to carry out this research work. The authors are also grateful to the anonymous reviewers and journal editorial board for their many insightful comments, which have significantly improved this article.

\section{REFERENCES}

Arduino. (2018, September 5). Arduino UNO Rev3. Taken back from https://store.arduino.cc/usa/arduino-unorev3

Edhy, Sutanta. (2004). Database System. Yogyakarta: Graha Science.

Hamzah, I., Bintangsyah, E. (2012). Design of Temperature and Humidity Monitoring in Arsenal Projectile Warehouse. Surabaya: Thesis STTAL.

Hartono, A. M. (2009). Information Technology Systems-Edition III. Yogyakarta: Andi Publisher. 
Jaya, I., Maryanto, E. (2017). Design and Development of the Navy's Army Heatstroke Early Detection System in IoT-Based Cross Country Military Sports. Surabaya: Thesis STTAL.

Jogiyanto, HM. (2005). Information System Analysis \& Design: Structured Approach to Business Theory and Practice Applications. Yogyakarta: Andi Offset.

Juanda, A. (2003). Wet Bulb Globe Temperature (WBGT). Retrieved from http://www.k Kesehatankerja.com

Kendall E Kenneth and Kendall E Julie. (2006). Systems Analysis and Design. Bandung: PT. Index.

Kroenke, DM. (2005). Database Processing: Basics, Design and Implementation. Jakarta: Erlangga.

Made, N., Pratiwi, E., \& Wirastuti, N. D. (2013). Development of Information Systems in Indonesia. Bandung: Media Komputindo.

Nugroho, Bunafit. (2007). Complete Guide to Mastering SQL Commands. Yogyakarta: PT. Transmedia.

Rozikin, C., Kurnianto, F., Ahmadi, A., \& Syaifi, M. (2018). DESIGN OF SHOOTING SCORE RECORDING INFORMATION SYSTEM BASED ON IMAGE PROCESSING. INTERNATIONAL JOURNAL OF ASRO - STTAL, 9(1), 136141. Retrieved from http://asrojournalsttal.ac.id/index.php/ASRO/article/view/ $\underline{239}$

Jaya, I., Maryanto, E., Bukit, A., \& Zulkifli, M. (2018). DESIGN AND DEVELOPMENT OF EARLY HEAT STROKE DETECTION SYSTEM IN MILITARY CROSS COUNTRY BASED ON IOT. INTERNATIONAL JOURNAL OF ASRO - STTAL, 9(2), 141-151. Retrieved from http://asrojournal-

sttal.ac.id/index.php/ASRO/article/view/ $\underline{241}$

Candra, D., Syahlan, Z., \& Widodo, E. (2019). DESIGN AND DEVELOPMENT OF THE MEASURING OF THE BODY MASS INDEX TO THE INDONESIA NAVY BASED ON VISUAL STUDIO.
INTERNATIONAL JOURNAL OF ASRO - STTAL, 10(2), 116-124. Retrieved from http://asrojournal-

sttal.ac.id/index.php/ASRO/article/view/ $\underline{237}$

Wibisono, B., Bukit, A., Bandono, A., \& Widodo, E. (2019). DESIGN AND DEVELOPMENT OF MORSE LEARNING SYSTEM APPLICATION BASED ON VISUAL BASIC. INTERNATIONAL JOURNAL OF ASRO - STTAL, 10(1), 105-111. Retrieved from http://asrojournal-

sttal.ac.id/index.php/ASRO/article/view/ $\underline{234}$

Faturrochman, M., Suprayitno, S., Zulkifli, M., \& Widodo, E. (2019). DESIGN OF FUEL'S VOLUME MONITORING SYSTEM ON INDONESIAN NAVY FUEL TANK "SPBT" BASED ON THE Internet of Things (IOT). INTERNATIONAL JOURNAL OF ASRO - STTAL, 10(1), 112-116. Retrieved from http://asrojournalsttal.ac.id/index.php/ASRO/article/view/ $\underline{235}$ 